\title{
Morphometric parameters comparisons of the digestive tract of four teleosts with different feeding habits
}

\author{
Comparações de parâmetros morfométricos do trato digestório de quatro teleósteos \\ com diferentes hábitos alimentares
}

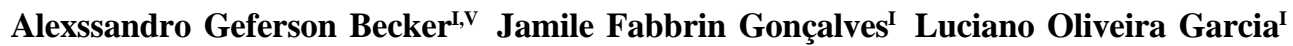 \\ Everton Rodolfo Behr ${ }^{\text {II }}$ Dominguita Luhers Graça ${ }^{\text {III }}$ Mário Kurtz Filho ${ }^{\text {IV }}$ Tessie Martins $^{\text {III }}$ \\ Bernardo Baldisserotto ${ }^{\mathrm{I}, \mathrm{V}^{*}}$
}

\begin{abstract}
The present study compared some morphometric parameters of the digestive tract of four teleosts with different feeding habits: traira (Hoplias malabaricus, carnivore), silver catfish (Rhamdia quelen, omnivore), hassar (Hoplosternum littorale, omnivore), and grass carp (Ctenopharyngodon idella, herbivore). The digestive tract was removed from fish collected from nature and fixed for some morphometric analyses, such as: intestinal quotient, intestinal area quotient, vilosity height, digestive somatic index, and hepatosomatic index. Grass carp showed the highest values of intestinal quotient and height vilosity. On the other hand, the intestinal area quotient was higher in traira than in the other species. The intestinal quotient can be used to estimate the feeding habit, and the intestinal area quotient, vilosity height and the relationships between digestive tract length and fish weight or digestive tract weight can provide important additional information to analyze the feeding habits.
\end{abstract}

Key words: gastrointestinal tract, intestine, morphological parameters, pyloric ceca.

\section{RESUMO}

O presente estudo comparou alguns parâmetros morfométricos do trato digestório de quatro teleósteos com diferentes hábitos alimentares: traira (Hoplias malabaricus, carnivoro), jundiá (Rhamdia quelen, omnivoro), tamoatá (Hoplosternum littorale, omnivoro) e carpa capim (Ctenopharyngodon idella, herbivoro). O trato digestório foi removido dos peixes coletados da natureza e em seguida fixado para algumas análises morfométricas, tais como: quociente intestinal, quociente da área intestinal, altura da vilosidade,

\begin{abstract}
índice digestivo somático e índice hepatossomático. Os maiores valores para o quociente intestinal e a altura das vilosidades foram encontrados em carpa capim. Por outro lado, o quociente da área intestinal foi maior na traira do que nas outras espécies. O quociente intestinal pode ser utilizado para estimar o hábito alimentar, e o quociente da área intestinal, a altura da vilosidade $e$ as relações entre o comprimento do trato digestório e o peso do peixe ou peso do trato digestório podem fornecer importantes informações adicionais para analisar o hábito alimentar.
\end{abstract}

Palavras-chave: trato gastrintestinal, intestino, parâmetros morfológicos, cecos pilóricos.

\section{INTRODUCTION}

In teleosts, the gastrointestinal tract morphology usually shows specific variations related to diet, feeding habit phylogeny, body shape, and also features that reflect functional differentiation (NOAILLAC-DEPEYRE \& GAS, 1974; KAPOOR et al., 1975; ANDERSON, 1986; ABAURREA et al., 1993). Moreover, there is a correlation between the structures of the digestive apparatus and the feeding habit of fishes (BARBIERI et al., 1994; BUDDINGTON et al., 1987; FUGI et al., 2001; WARD-CAMPBELL et al., 2005). The morphological structures give insights on the feeding ecology of a species, since these peculiarities

IDepartamento de Fisiologia e Farmacologia, Universidade Federal de Santa Maria (UFSM), 97105-900, Santa Maria, RS, Brasil.

E-mail: bernardo@smail.ufsm.br.*Autor para correspondência.

IIUnidade Descentralizada de Educação Superior de Silveira Martins, UFSM, Silveira Martins, RS, Brasil.

IIIDepartamento de Patologia, UFSM, Santa Maria, RS, Brasil.

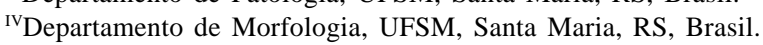

vPrograma de Pós-graduação em Zootecnia, UFSM, Santa Maria, RS, Brasil. 
suggest how a fish is able to feed (WARD-CAMPBELL et al., 2005). In addition, in Coregonus schinzi palea the diet influences the intestinal morphology (DABROWSKI \& KAUSHIK, 1985).

Studies regarding feeding in fishes from tropical regions usually reported diet composition and feeding periodicity (PEREIRA et al., 1982; WINEMILLER, 1987; BARBIERI et al., 1994; KIRKAGAÇ, 2003), but for interpretation of feeding habits, is also important to analyze morphometric parameters of the digestive tract. The gastrointestinal tract shows a high variability in structure according to diet (BUDDINGTON et al., 1987). It is commonly emphasized that herbivore and detritivore fish species tend to have longer, thinner and narrower intestines than carnivores (FANGE \& GROVE, 1979; JUNGER et al., 1989, FUGI et al., 2001), and the intestine of omnivores species have an intermediate length (WARD-CAMPBELL et al., 2005). Intestinal length and area could be affected by the feeding habits (BUDDINGTON et al., 1987). Therefore, the aim of this study was to analyze some morphometric parameters of the digestive tract, such as: intestinal quotient, intestinal area quotient, vilosity height, digestive somatic index, and hepatosomatic index of four teleosts with different feeding habits. The results should provide important basic information for increasing our understanding about the influence of the feeding habit in the digestive tract of teleost fish and, also signaling which parameters might be used as indicators of the feeding habits.

\section{MATERIAL AND METHODS}

Teleosts of four species with different feeding habits, traira (Hoplias malabaricus; Bloch, 1794; Erythrinidae) $(\mathrm{n}=9)$, silver catfish (Rhamdia quelen; Quoy \& Gaimard, 1824; Heptapteridae) ( $n=7$ ), hassar (Hoplosternum littorale; Hancock, 1828; Callichthyidae) $\quad(n=9)$, and grass carp (Ctenopharyngodon idella; Valenciennes, 1844; Cyprinidae) ( $n=8)$ (Table 1), were collected with nets placed in ponds at the campus of the Federal University of Santa Maria in Santa Maria (2941’02"S 5348’25"O), Southern Brazil. The feeding habits considered were: carnivore, omnivore and herbivore. Classification into these categories was based on specific references of feeding habits for each species: traira (PEREIRA et al., 1982), silver catfish (GOMES et al., 2000), hassar (WINEMILLER, 1987) and grass carp (KIRKAGAÇ, 2003). Species were considered carnivores, omnivores or herbivores only when references stated that at least $80 \%$ of their meal was based on the specified food.
The fishes were apparently healthy, and after collection were transported to the Fish Physiology Laboratory and kept in aerated 250-l tanks for at most 2h. The fishes took a blow to the head and then were euthanized by spinal cord section, weighed, and measured.

The digestive tract of traira was dissected following the guidelines of MENIN \& MIMURA (1992) into stomach, pyloric ceca, mid-intestine (starts after the last pyloric ceca and ends at the ileum rectal valve), and posterior intestine. Regarding to the other species, the digestive tract was separated as follow: silver catfish (stomach, anterior, mid- and posterior intestine), hassar (stomach, anterior and posterior intestine) and grass carp (without stomach), and was also separated in oesogaster (the expanded proximal region of the intestine: $15-20 \%$ of total intestinal length), and midand posterior intestine, following the guidelines of BUDDINGTON et al. (1987). After emptying the content of the segments, the morphometric parameters were measured or calculated, and these segments were fixed in 10\% buffered formalin ( $\mathrm{pH} \mathrm{6.8-7.0).} \mathrm{Tissues} \mathrm{were}$ then embedded in paraffin blocks, sectioned at $5 \mu \mathrm{m}$ and stained with hematoxylin and eosin for morphometric analysis. The analysis of the digestive tract of traira was made only in the pyloric ceca and intestine, because the stomach was previously described by MENIN \& MIMURA (1992). All vilosities of each segment were measured with a graduate ruler under an optic microscope (Lambda LMR - 2) at a magnification of $100 \mathrm{X}$. The intestinal area (IA) was calculated using the following equations for each species:

traira: $\mathrm{IA}=\mathrm{A}+\mathrm{B}$.

$\mathrm{A}=$ pyloric ceca area by equation: (vilosity perimeter $\mathrm{x}$ number of vilosities) $\mathrm{x}$ number of pyloric ceca $\mathrm{x}$ pyloric ceca length.

$\mathrm{B}=$ intestinal area by equation: (vilosity perimeter $\mathrm{x}$ number of vilosities) $\mathrm{x}$ intestinal length.

silver catfish, hassar and grass carp: IA=B.

Other measured parameters were: IQ=Intestinal Quotient (Intestine length/total length); HSI=Hepatosomatic Index [(liver weight/body weight)x100]; DSI=Digestive Somatic Index [(digestive tract weight/body weight) $\mathrm{x} 100]$; DL/FW=Digestive tract Length/ Fish Weight; DL/DW= Digestive tract Length/Digestive tract Weight; VH=Vilosity Height; IAQ=Intestinal Area Quotient (Intestinal Area/Body Weight); ITW/IA=Intestinal Total Weight/Intestinal Area.

All data are expressed as means \pm SEM. Homogeneity of variances among species was tested with the Levene's test. Comparisons among the 
Table 1 - Body and morphometric measurements of fish species studied. IQ=Intestinal Quotient (Intestine length/total length); VH=Vilosity Height; IAQ=Intestinal Area Quotient (Intestinal Area/ Body Weight); ITW/IA=Intestinal Total Weight/Intestinal Area; HSI=Hepatosomatic Index [(liver weight/body weight)x100]; DSI=Digestive Somatic Index [(digestive tract weight/body weight)x100]; DL/FW=Digestive tract Length/Fish Weight; DL/DW=Digestive tract Length/Digestive tract Weight.

\begin{tabular}{|c|c|c|c|c|}
\hline & traira & silver catfish & hassar & grass carp \\
\hline Feeding habit & Piscivore & Omnivore & Omnivore & Herbivore \\
\hline Body weight (g) & $581.0 \pm 81.5$ & $516.4 \pm 60.8$ & $304.9 \pm 25.9$ & $1728.3 \pm 291.5$ \\
\hline Total length(cm) & $38.2 \pm 1.6$ & $37.6 \pm 1.0$ & $24.4 \pm 0.6$ & $53.3 \pm 3.2$ \\
\hline IQ & $0.51 \pm 0.02^{\mathrm{c}}$ & $0.65 \pm 0.06^{\mathrm{c}}$ & $1.36 \pm 0.03^{b}$ & $2.78 \pm 0.09^{\mathrm{a}}$ \\
\hline $\operatorname{IAQ}\left(\mathrm{cm}^{2} \mathrm{~g}^{-1}\right)$ & $0.78 \pm 0.03^{\mathrm{a}}$ & $0.21 \pm 0.02^{c}$ & $0.18 \pm 0.01^{\mathrm{c}}$ & $0.58 \pm 0.03^{b}$ \\
\hline $\mathrm{VH}(\mathrm{mm})$ & $1.12 \pm 0.04^{\mathrm{b}}$ & $1.15 \pm 0.06^{\mathrm{b}}$ & $0.58 \pm 0.03^{c}$ & $1.99 \pm 0.14^{\mathrm{a}}$ \\
\hline ITW/IA $\left(\mathrm{mg} \mathrm{cm}^{-2}\right)$ & $18.63 \pm 1.14^{\mathrm{c}}$ & $82.63 \pm 5.21^{\mathrm{a}}$ & $68.36 \pm 3.72^{a}$ & $38.36 \pm 2.06^{\mathrm{b}}$ \\
\hline HSI & $1.15 \pm 0.13^{\mathrm{a}}$ & $1.08 \pm 0.11^{\mathrm{a}}$ & $1.19 \pm 0.11^{\mathrm{a}}$ & $1.53 \pm 0.08^{\mathrm{a}}$ \\
\hline DSI & $2.53 \pm 0.25^{\mathrm{a}}$ & $1.98 \pm 0.20^{\mathrm{a}}$ & $1.87 \pm 0.20^{\mathrm{a}}$ & $2.00 \pm 0.22^{\mathrm{a}}$ \\
\hline $\mathrm{DL} / \mathrm{FW}\left(\mathrm{cm} \mathrm{g}^{-1}\right)$ & $5.69 \pm 0.60^{\mathrm{b}}$ & $5.31 \pm 0.26^{\mathrm{b}}$ & $11.61 \pm 0.60^{\mathrm{a}}$ & $9.73 \pm 0.87^{\mathrm{a}}$ \\
\hline $\mathrm{DL} / \mathrm{DW}\left(\mathrm{cm} \mathrm{g}^{-1}\right)$ & $2.47 \pm 0.52^{\mathrm{c}}$ & $2.56 \pm 0.36^{\mathrm{c}}$ & $7.33 \pm 0.58^{\mathrm{a}}$ & $4.59 \pm 0.24^{\mathrm{b}}$ \\
\hline
\end{tabular}

Means \pm SEM. Different letters in the rows indicate significant difference among species by one-way ANOVA and Tukey test (P<0.05), or Kruskall - Wallis ANOVA and Mann - Whitney test (DSI) $(\mathrm{P}<0.05)$.

different species were made by one-way analysis of variance and Tukey test or, when homogeneity among the species was not obtained (DSI), by Kruskall-Wallis ANOVA and Mann-Whitney test. Analysis was performed using the software Statistica (version 5.1), and the minimum significance level was set at $\mathrm{P}<0.05$.

\section{RESULTS AND DISCUSSION}

Interpretations of feeding habits based only in isolated analysis of gastrointestinal content items might lead to incorrect conclusions, because the frequency of these items usually is related with their availability in the environment (BARBIERI et al., 1994). In addition, the digestion rate of the different food items varies, and the presence of less easily digested items in the stomach may overestimate their importance in the diet of a given species (ROSS et al., 2006).

The significantly highest intestinal quotient was observed in grass carp, followed by hassar and after traira and silver catfish, which were statistically similar (Table 1). WARD-CAMPBELL et al. (2005) stated that intestinal quotient below one indicate a carnivore diet, between one and three indicate an omnivore diet and over three a herbivore or detritivore diet. The intestinal quotient of traira calculated in the present study (0.51) is within the expected range for a carnivorous species and similar to values reported by MENIN \& MIMURA (1992) and BARBIERI et al. (1994) for the same species. The value of the intestinal quotient of hassar (1.36) is in the range suggested by
WARD-CAMPBELL et al. (2005) for omnivorous species, but the intestinal quotient of silver catfish (0.65) is in the range of carnivorous species. A similar value (0.76) was found by BARBIERI et al. (1994).

Silver catfish is an omnivore with carnivore tendency (OLIVEIRA-FILHO \& FRACALOSSI, 2006). The obtained value for the intestinal coefficient also indicates a carnivore tendency for this species. The minimum value (3.0) suggested by WARD-CAMPBELL et al. (2005) for herbivore species apparently is not correct because the values of the intestinal quotient for grass carp found in the present study (2.78), that are reported by BUDDINGTON et al. (1987) for the same species (1.90) and DREWE et al. (2004) for large herbivore specimens of Brycon guatemalensis (Regan, 1908; Characidae) (2.3) are below this value. Consequently, in spite of being a helpful parameter, the use of the intestinal quotient as a single parameter to determine the feeding habit it is not recommended.

The highest value of the intestinal area quotient was observed in traira, followed by grass carp. This value was statistically similar in silver catfish and hassar. The intestinal area quotient of the studied species in the present study decreased in the following order: carnivores $>$ herbivores $>$ omnivores. However, BUDDINGTON et al. (1987) reported that the intestinal area quotient was higher in carnivores and herbivores than omnivores. It is possible that the use of a different methodology to calculate the intestinal area led to the different results in this parameter, because in the study of BUDDINGTON et al. (1987) intestinal area was 
calculated considering the intestine and the pyloric ceca as smooth-bore cylinders.

The vilosity height was significantly lowest in hassar compared to the other species. On the other hand, the highest value of this parameter was found in grass carp (Table 1). Silver catfish and traira present similar values of intestinal quotient and vilosity height, but the intestinal area quotient is significantly lower in silver catfish. Probably this is due to the presence of the pyloric ceca in traira, which according to BUDDINGTON \& DIAMOND (1987) increases the intestinal area of the anterior intestine. Moreover, the lowest intestinal area quotient found in hassar might be explained by the much lower vilosity height compared to the other species.

BUDDINGTON \& DIAMOND (1987) stated that herbivores distribute their absorptive tissue along a long thin intestine, while carnivores concentrate it in a short thick intestine and/or pyloric ceca. However, the findings of the present study do not support this affirmative regarding to the intestinal thickness and feeding habit. The omnivores analyzed in the present study, silver catfish and hassar, have the lowest intestinal area quotient and also the highest values in the relationship intestinal total weight/intestinal area, which indicates that their intestines are thicker than those from traira and grass carp.

The values for the digestive somatic and hepatosomatic indexes of the studied species were similar to those reported by HIDALGO et al. (1999) for omnivores and carnivores species, except HSI values for omnivore species, which were lower in the present study. However, in this study no significant difference between the studied species was found (Table 1), indicating that these parameters could not be used to determine the feeding habit. The results of the digestive somatic index were expected because according to BUDDINGTON \& DIAMOND (1987) fishes of a given body weights have similar gut weights, regardless of their feeding habit.

The quotient digestive tract length/fish weight (DL/FW) was higher in hassar and grass carp than in the other species. The digestive tract length/ digestive tract weight was significantly highest in hassar followed by grass carp and after traira and silver catfish, which were statistically similar. The highest values of intestine total weight/ intestinal area were found in silver catfish and hassar (Table 1). In agreement with these results, HIDALGO et al. (1999) also found higher values for both parameters in omnivore and herbivore species, followed by carnivore species. The presence of a stomach with thick muscular walls, which increase digestive tract weight, is an important factor to explain the lower values found in the digestive tract length and fish weight or digestive tract weight in traira and silver catfish.

\section{CONCLUSION}

The intestinal quotient might be used to estimate the feeding habits, but the value of this parameter in some omnivores and herbivores teleosts species fall in an indeterminate range, and some additional parameters must be used. The intestinal area quotient, vilosity height and the relationships between digestive tract length and fish weight or digestive tract weight can provide important additional information to analyze the feeding habit, but as only data from a few species are available, additional studies must be performed to state if these parameters show a relationship with the feeding habit.

The methodology of this experiment was approved by the Ethical and Animal Welfare Committee of the Federal University of 1 Santa Maria.

\section{ACKNOWLEDGEMENTS}

A.G. Becker and B. Baldisserotto received Conselho Nacional de Desenvolvimento Científico e Tecnológico (CNPq), research grants.

\section{REFERENCES}

ABAURREA, M.A. et al. Ultrastructural study of the distal part of the intestine of Oncorhynchus mykiss. Absorption of dietary protein. Micron, v.24, n.5, p.445-450, 1993. Disponível em: < h t t p : / / w w w. s c i e n c e d i r e c t. c o m/ s c i ence? _ ob = Article URL \&_u di = B 6 T $9 \mathrm{~N}$ -

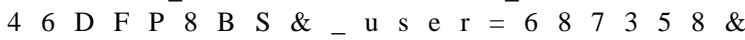
c over D a te $=12 \% 2$ F $31 \% 2$ F 1993 \&_rd o c $=$ 2 \&_f m t $=$ hig h \&_orig $=$ b r o w s e \&_s r c h $=$ d o c i n f o ( \% 23 t o c \% $235119 \% 231993 \% 2399$ 9759994\%23329596\%23FLP\%23display\%23Volume)\&_cdi=5 1198 \& sort $=$ d\&_docanchor $=\&$ \& ct $=9 \&$ \& acct $=C 000037899 \&$ \&ersion $=1 \&$ u r l V e r s i o $n=0 \&$ u s e r i d $=687358 \&$ m $\mathrm{d} 5=32329 \mathrm{f} 84 \mathrm{a} 5 \mathrm{a} 70 \mathrm{~b} 2 \mathrm{ec} 6 \mathrm{~b} 2391 \mathrm{bb77aa99d}>$. Acesso em: 02 set. 2009. doi: 10.1016/0968-4328(93)90022-S

ANDERSON, T.A. Histological and cytological structure of the gastrointestinal tract of the luderick, Girella tricuspidata (Pisces, Kyphosidae), in relation to diet. Journal of Morphology, v.190, n.1, p.109-119, 1986. Disponível em: <http://www3.interscience.wiley.com/journal/109919841/ abstract $>$. Acesso em: 30 nov. 2009. doi: 10.1002/ jmor. 1051900110 .

BARBIERI, G. et al. Notas sobre a adaptação do trato digestivo ao regime alimentar em espécies de peixes da região de São Carlos (SP) I. Quociente intestinal. Revista Brasileira de Biologia, v.54, p.63-69, 1994.

BUDDINGTON, R.K.; DIAMOND, J.M. Pyloric caeca of fish, a "new" absorptive organ. American Journal of Physiology, v.252, p.G65-G76, 1987. Disponível em: <http:// 
ajpgi.physiology.org/cgi/content/abstract/252/1/G65>. Acesso em: 02 set. 2009.

BUDDINGTON, R.K. et al. Genetic and phenotypic adaptation of intestinal nutrient transport to diet in fish. Journal of Physiology, v.393, p.261-281, 1987. Disponível em: <http:/ /jp.physoc.org/content/393/1/261.full.pdf+html>. Acesso em: 02 set. 2009.

DABROWSKI, K.; KAUSHIK, S.J. Rearing of coregonid (Coregonus schinzi palea Cuv. et Val.) larvae using dry and live food. III Growth of fish and developmental characteristics related to nutrition. Aquaculture, v.48, n.2, p.123-135, 1985. Disponível em: <http:/ /www.sciencedirect.com/science?_ob=ArticleURL\&_udi=B6T4D49NPMM7-1C6\&_user $=687358 \&$ _coverDate $=09 \% 2 \mathrm{~F} 0$ $1 \% 2 \mathrm{~F} 1985 \&$ \&doc $=3 \&$ \& fmt $=$ high\&_orig=browse\&_srch $=$ doc infor $\% 23$ t o c \%234972\%231985\%2399 $9519997 \% 23460986 \% 23$ F L P \% 23 display \% 23 Volume) \&_cdi $4972 \&$ _sort $=$ d \&_docanc hor $=\&_{-}$ct $=7 \&_{\text {_ a c c t }}=\mathrm{C} 000037899 \&_{\text {_vers }}$

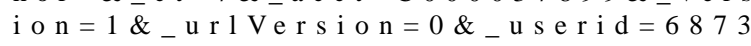
58\&md5=931c4661e525d46d42434dec9b9efe1c $>$. Acesso em: 30 nov. 2009. doi: 10.1016/0044-8486(85)90099-7.

DREWE, K.E. et al. Insectivore to frugivore: ontogenetic changes in gut morphology and digestive enzyme activity in the characid fish Brycon guatemalensis from Costa Rica rain forest streams. Journal of Fish Biology, v.64, n.4, p.890-902, 2004. Disponível em: <http://www3.interscience.wiley.com/journal/118755936/ abstract>. Acesso em: 02 set. 2009. doi: 10.1111/j.10958649.2004.0357.x.

FANGE, R.; GROVE, D. Digestion. In: HOAR, W.S.; et al. . Fish physiology. New York: Academic, 1979. p.162-260.

FUGI, R. et al. Trophic morphology of five benthic-feeding fish species of a tropical floodplain. Brazilian Journal of Biology, v.61, n.1, p.27-33, 2001. Disponível em: <http:// www.scielo.br/scielo.php?script=sci_arttext\&pid=S003471082001000100005>. Acesso em: 02 set. 2009. doi: 10.1590/ S0034-71082001000100005.

GOMES, L.C. et al. Biologia do jundiá (Rhamdia quelen; Teleostei, Pimelodidae). Ciência Rural, v.30, n.1, p.179-185, 2000. Disponível em: <http://www.scielo.br/scielo.php?script=sci_abstract\&pid=S0 $10384782000000100029 \& \operatorname{lng}=p t \& n r m=i s o \& t \operatorname{lng}=e n>$. Acesso em: 02 set. 2009. doi: 10.1590/S0103-84782000000100029.

HIDALGO, M.C. et al. Comparative study of digestive enzymes in fish with different nutritional habits. Proteolysis and amylase activities. Aquaculture, v.170, p.267-283, 1999. Disponível em: $<\mathrm{h} \mathrm{t} \mathrm{t} \mathrm{p} \mathrm{:} \mathrm{/} \mathrm{/} \mathrm{w} \mathrm{w} \mathrm{w.} \mathrm{s} \mathrm{c} \mathrm{i} \mathrm{e} \mathrm{n} \mathrm{c} \mathrm{e} \mathrm{di} \mathrm{re} \mathrm{c} \mathrm{t} \mathrm{.} \mathrm{c} \mathrm{o} \mathrm{m/}$ science?_ob=ArticleURL\&_udi=B6T4D3VFF51MJ\&_user=687358\&_coverDate=01 \%2F 15\%2F1999\&_rdoc $=8 \&$ \&mt $=$ high \&_orig=browse \&_s r c h $=$ d o cinfo ( \% 23 to c \% $234972 \%$ $231999 \% 23998299996 \% 2344911 \% 23 \mathrm{~F}$ LA\%23display\%23Volume)\&_cdi=4972\&_sort=d\&_docanchor=\&_c $\mathrm{t}=14 \&$ \& acct $=C 000037899$ \&_version $=1 \&$ \&urlVersion $=0$ \& _userid=687358\&md5=a86b18d767fe6bc9451220e90da80c7d $>$. Acesso em: 02 set. 2009. doi: 10.1016/S0044-8486(98)00413-X.

JUNGER, H. et al. Comparative morphology and ecomorphology of the gut in European cyprinids. Journal of
Fish Biology, v.34, n.2, p.315-326, 1989. Disponível em: $<$ http://www3.interscience.wiley.com/journal/119432175/ abstract>. Acesso em: 02 set. 2009. doi: 10.1111/j.10958649.1989.tb03312.x.

KAPOOR, B.G. et al. The alimentary canal and digestion in teleosts. In: RUSSEL, F.S.; YONGE, C.M. Advances in marine biology. London: Academic, 1975. V.13, p.109-239.

KIRKAGAÇ, M.U. The gut contents of grass carp, Ctenopharyngodon idella, during nursing in an earthen pond. Israeli Journal Aquaculture-Bamidgeh, v.55, n.2, p.139143, 2003. Disponível em: <http://www.siamb.org.il/uploads/ 55_2_Kirkajac_abs.pdf $>$. Acesso em: 02 set. 2009.

MENIN, E.; MIMURA, O.M. Anatomia comparativa do intestino de duas espécies de peixes teleósteos de hábitos alimentares distintos. Revista Ceres, v.39, p.308-341, 1992.

NOAILLAC-DEPEYRE, J.; GAS, N. Fat absorption by the enterocytes of the carp (Cyprinus carpio L.). Cell \& Tissue Research, v.155, n.3, p.353-365, 1974. Disponível em: <http:/ /www.springerlink.com/content/rl71258127168582/ ?p=575c9f2993c6495d915091acf2cbe2b8\&pi=4>. Acesso em: 02 set. 2009. doi: 10.1007/BF00222811.

OLIVEIRA-FILHO, P.R.C.; FRACALOSSI, D.M. Coeficientes de digestibilidade aparente de ingredientes para juvenis de jundiá. Revista Brasileira de Zootecnia, v.35, n.4, p.15811587, 2006. Disponível em: <http://www.scielo.br/ scielo.php ? script =sci_abstract \& pid=S 1516 $35982006000600002 \& \operatorname{lng}=$ en $\& \mathrm{nrm}=\mathrm{iso} \& \mathrm{tlng}=\mathrm{pt}>$. Acesso em: 02 set. 2009. doi: 10.1590/S1516-35982006000600002.

PEREIRA, G.S. et al. Contribución al conocimiento de la ecología alimentaría de algunos peces del lago Valencia (Venezuela). Memorias de la Sociedad de Ciencias Naturales “La Salle”, v.17, p.41-56, 1982.

ROSS, L.G. et al. Determination of feeding mode in fishes: the importance of using structural and functional feeding studies in conjunction with gut analysis in a selective zooplanktivore Chirostoma estor estor Jordan 1880. Journal of Fish Biology, v.68, n.6, p.1782-1794, 2006. Disponível em: <http:// www3.interscience.wiley.com/journal/118560041/abstract>. Acesso em: 02 set. 2009. doi: 10.1111/j.10958649.2006.01061.x.

WARD-CAMPBELL, B.M.S. et al. Morphological characteristics in relation to diet in five coexisting Thai fish species. Journal of Fish Biology, v.67, n.5, p.1266-1279, 2005. Disponível em: <http://www3.interscience.wiley.com/ journal/118686705/abstract>. Acesso em: 02 set. 2009. doi: 10.1111/j.1095-8649.2005.00821.x.

WINEMILLER, K.O. Feeding and reproductive biology of the currito, Hoplosternum littorale, in the Venezuelan llanos with comments on the possible function of the enlarged male pectoral spines. Environmental Biology of Fishes, v.20, n.3, p.219227, 1987. Disponível em: <http://www.springerlink.com/ c o n t e n t / h 8122118 v $3 \begin{array}{llllllll}6 & 6 & 5 & 8 & 7 & 7 & 3\end{array} /$ ?p=7adcf93ad28840b3af6757b4d6c6d980\&pi=5>. Acesso em: 02 set. 2009. doi: 10.1007/BF00004956. 